\title{
Air Quality and Environmental Health in Calabar, Cross River State, Nigeria.
}

\author{
Ewona, I. O. ${ }^{\mathrm{A}}$, Osang, J. E, ${ }^{\mathrm{A}}$ Obi, E. O., ${ }^{\mathrm{A}}$ Udoimuk A. B. $^{\mathrm{B}}$, Ushie, P. O. \\ A. Department Of Physics, Cross River University Of Technology Calabar, Nigeria \\ ${ }^{B}$. Department Of Physics, University Of Calabar, Calabar
}

\begin{abstract}
Our scientific understanding of the spectrum of environmental health effect of air pollution has increased, and numerous studies are finding important health effects from air pollution at levels once considered safe. This paper focuses on air pollution and its adverse health outcomes in Calabar. The Data for Temperature $\left({ }^{0} \mathrm{C}\right)$, Relative Humidity (\%), wind speed $(\mathrm{m} / \mathrm{s})$, pressure (psi), Cloud Cover (oktas), Heat Radiation $\left(\mathrm{kw} / \mathrm{m}^{3}\right)$, wind Direction, $\mathrm{NO}_{2}(\mathrm{ppm}), \mathrm{NO}(\mathrm{ppm}), \mathrm{O}_{2}, \mathrm{SO}_{2}(\mathrm{ppm}), \mathrm{H}_{2} \mathrm{~S}(\mathrm{ppm}), \mathrm{CO}_{2}, \mathrm{VOC}(\mathrm{ppm}), \mathrm{NH}_{3}$ (ppm), SPM (ppm) and Noise dBA were Collected from Environmental Impact Assessment (EIA) Cross River State Ministry of Environment in conjunction with Niger Delta Development Commission which Covers a period of two years (October 2010 to September 2012). The data obtained were daily values from which future assumptions were made. Based on these data, a simple Descriptive analysis was employed. The results shown in tables 2,3,4,5,6,7,8,9 and figs 1,2,3,4,5,6,7,8,9,10,11,12 recorded a non significant value of $\mathrm{CO}, \mathrm{CO}_{2}, \mathrm{NO}_{2}, \mathrm{HO}_{2}$ $\mathrm{H}_{3}, \mathrm{CH}_{4}$ and VOCs. The statement however provides advice to health providers on how to integrate issues regarding air quality and environmental health into patient education and environmental health advocacy. There are also recommendations to the government, industries and the general public on the promotion of effective air pollution policies to ensure continued protection of lives.
\end{abstract}

Key Words: Environmental issues, air pollution, air quality and health

\section{Introduction}

All round the earth, there is a thick blanket of air called the atmosphere. Air, like other gases, does not have a fixed shape. It spread out to fill any available space, so nothing is really empty. But air cannot escape from the atmosphere as the force of gravity keeps it from floating away from the earth. Air is one of the major components that man needs to survive in this planet. Therefore the quality of the air we breathe has a greater contribution to the comfort of man's existence on earth. And as such, the source of air and its composition are very important in this study. It does not matter who you are, where you live or the state of your health, the quality of air you breathe each day affects you.

Ever since people first gathered, there has been pollution. Pollution usually refers to the presence of substances that are either present in the environment where it doesn't belong to or at levels greater than it should be. According to Ewona et al 2012, referring to IPPC (1992), posited that the major cause of climate change is the release of greenhouse gases. Some of these gases especially $\mathrm{CO}_{2}$ and oxides of nitrogen are dissolved in rain water and fall back as acid rain which will in turn pollute the air. Obi et al (2008), in their work on the basic source of oil pollution at the coastal waters of the republic of Nigeria say that, accidents at the oil extracting plat forms, accidents by tankers transporting crude or refined oil through the sea and by old/rusted oil pipelines are also a major source of air pollution. Osang et al (2013) pointed out that a good number of scientist, engineers, laboratory users have lost their lives and the lives of others due to accidents in the workshops caused by ignorance, neglect, or carelessness. In this paper, the earth is represented as the workshop. While we (man) are suffering the effects of air pollution from accidents due to ignorance, neglect and carelessness.

Air pollution is caused by any undesirable substance, which enters the atmosphere. Air pollution is a major problem in modern society. Even though air pollution is usually a greater problem in cities, pollutants contaminate air everywhere. These substances include various gases and tiny particles, or particulates that can harm human health and damage the environment. They may be gases, liquids, or solids. Many pollutants are given off into the air as a result of human behaviour. Pollution occurs at different levels: personal, national, and global. Air pollution is mainly composed of gas and particulate matter (PM). The main gases that contaminate the air are ozone $\left(\mathrm{O}_{3}\right)$, nitrogen dioxide $\left(\mathrm{NO}_{2}\right)$, sulphur dioxide $\left(\mathrm{SO}_{2}\right)$, and carbon monoxide $(\mathrm{CO})$. PM can be classed according to size: $\mathrm{PM}$ of less than 10 micrometers $\left(\mathrm{PM}_{10}\right)$ and $\mathrm{PM}$ of less than 2.5 micrometers $\left(\mathrm{PM}_{2.5}\right)$. The smaller particles can penetrate deep into the lungs.

The main air contaminants come from sources like motor vehicles, industrial processes, heating (oil, wood, propane, etc.), and forest fires. These contaminants can be harmful to health and the environment. They are typically used as air quality indicators and should be subject to continuous monitoring by local and federal agencies. 


\section{Some pollutants come from natural sources}

- Forest fires emit particulates, gases, and VOCs (substances that vaporize into the atmosphere).

- Ultra-fine dust particles created by soil erosion when water and weather loosen layers of soil, increase airborne particulate levels.

- Volcanoes spew out sulfur dioxide and large amounts of pulverized lava rock known at volcanic ash.

Air pollution is now recognized as an important problem, both nationally and worldwide. Our scientific understanding of the spectrum of health effects of air pollution has increased, and the air pollution, both indoors and outdoors, is a major environmental health problem affecting every one in developed and developing countries alike. This study is centered on the following;

1) Major Types/source of air pollution

2) Air quality index

3) Environmental hazard and health effects

4) Prevention

\section{Major types and sources of air pollution}

Gaseous Pollutions: A different mix of vapors and gaseous air pollutants is found in outdoor and indoor environments. The most common gaseous pollutants are carbon dioxide, carbon monoxide, hydrocarbons, nitrogen oxides, sulfur oxides and ozone. A number of sources produce these chemical compounds but the major man-made source is the burning of fossil fuel. Indoor air pollution is caused by cigarette smoking, the use of certain construction materials, cleaning products, and home furnishings. Outdoor gaseous pollutants come from volcanoes, fires, and industries, and in some areas may be substantial. The most commonly recognized type of air pollution is smog. Smog generally refers to a condition caused by the action of sunlight on exhaust gases from motor vehicles and factories.

The Greenhouse effect prevents the sun's heat from rising out of the atmosphere and flowing back into space. This warms the earth's surface causing the green house effect. While a certain amount of green house gases in the atmosphere are necessary to make the earth warm, activities such as the burning of fossil fuels are creating a gaseous layer that is too dense to allow some heat escape. Scientists believe this is causing global warming. Other gases contributing to the problem include chlorofluorocarbons (CFC), methane, nitrous oxides.

Acid rain forms when moisture in the air interacts with nitrogen oxide and sulfur dioxide released by factories, power plants, and motor vehicles that burn coal or oil. This interaction of gases with water vapor forms sulfuric acid and nitric acids. Eventually these chemicals fall to earth as precipitation, or acid rain. Acid pollutants may travel long distances, with winds carrying them thousands of miles before they fall as dew, drizzle, fog, snow or rain.

Damage to the ozone layer is primarily caused by the use of chlorofluorocarbons (CFCs). Ozone is a form of oxygen found in the earth's upper atmosphere. The thin layer of ozone molecules in the atmosphere absorb some of the sun's ultraviolet (VP) rays before it reaches the earth's surface, making life on earth possible. The depletion of ozone is causing higher levels of UV radiation on earth, endangering both plants and animals.

Particulate matter is the general term used for a mixture of solid particles and liquid droplets found in the air. Some particles are large or dark enough to be seen as soot or smoke. Others are so small they can be detected only with an electron microscope. When particulate matter is breathed in, it can irritate and damage the lungs causing breathing problems. Fine particles are easily inhaled deeply into the lungs where they can be absorbed into the blood stream embedded for long periods of time.

Climates effects: Normally, pollutants rise or flow away from their sources without building up to unsafe levels. Wind patterns, clouds, rain, and temperature can affect how quickly pollutants move away from an area. Weather patterns that can trap air pollution in valleys or move it across the globe may be able to damage pristine environments far from the original sources.

\section{AIR QUALITY INDEX(AQI):}

Air index is a tool used by EPA and other agencies to provide the public with timely and easy-tounderstand information on local air quality and whether air pollution levels pose a health concern. AQI tells the public how clean the air is and whether or not they should be concerned for their health. AQI is focused on health effects that can happen within a few hours or days after breathing polluted air. 
Table 1: Table of Air Quality Index Value

\begin{tabular}{|l|l|l|}
\hline Air Quality index (AQI) Values & Levels of Health Concern & Colours \\
\hline When the AQI is in this range & Air quality conditions are: & As symbolized by this color \\
\hline 0 to 50 & Good & Green \\
\hline 51 to 100 & Moderate & Yellow \\
\hline 101 to 150 & Unhealthy for sensitive Groups & Orange \\
\hline 151 to 200 & Unhealthy & Red \\
\hline 201 to 300 & Very unhealthy & Purple \\
\hline 301 to 500 & Hazardous & Maroon \\
\hline
\end{tabular}

\section{Environmental Hazard and Health Effect}

According to Udo et al (2008), hamattan haze and increased aerosols in the sky due to bush burning activities influence the quality of air on earth. Many studies have shown links between pollution and health effects. Increases in air pollution have been linked to decreases in lung function and increases in heart attacks. High levels of air pollution according to the EPA Air Quality Index directly affect people with asthma and other types of lung or heart diseases. Overall air quality has improved in the last 20 years but urban areas are still in concern. The elderly and children are especially vulnerable to the effects of air pollution.

The level of risk depends on several factors;

- The amount of pollution in the air

- The amount of air we breathe in a given time

- Our overall health

Other less direct ways people are exposed to air pollutants are;

- Eating food products contaminated by air toxins that have been deposited where they grew

- Drinking water contaminated by air pollutants

- Ingesting contaminated soil

- Touching contaminated soil, dust or water.

Although many air pollutants are invisible, they can seriously impact our health, the environment, and our quality of life. Air pollutants may cause respiratory diseases, cancer and other health effects. Pollutants also may create odors and smog, diminish the protective ozone layer, and contribute to other environmental problems, such as acid rain and global climate change. The air inside homes, schools, and other buildings also may contain pollutants that enter from outdoors and those generated indoors. Mold, radon, tobacco smoke, carbon monoxide, and chemical emissions from products and furnishings are some of the important pollutants that may be present in our homes and other indoor environments.

The Air pollution and Respiratory Health Program (APRHP) leads CDCs fight against environmentalrelated respiratory illness, including asthma, cancer and other forms of illness.

\section{Asthma:}

Asthma is a serious environmental health threat, but it can be controlled by taking medication and by avoiding contact with environmental "triggers" such as dust mites, furry pets, mold, tobacco smoke, and certain chemicals. CDC works with state grantees to reduce the number of deaths, hospitalizations, emergency department visits, school days or workdays missed, and limitation on activity due to asthma.

Cancer:

A cancer cluster is a greater-than-expected number of cases that occurs within a group of people in a geographic area over a period of time. CDC provides cancer cluster information and resources, responds to inquiries about cancer clusters, and works with state health departments to address public health concerns about potential cancer clusters. The most common symptoms associated with short-term exposure to pollution (a few minutes to a few days) are:

- Irritation of the respiratory tract (cough, irritated throat);

- Wheezing

- Tightness in the chest

- Pain while deep breathing

- Difficulty breathing

\section{Geography of the area:}

\section{Materials and method}

This work was carried out in Calabar metropolis, the capital of cross river state. And is composed of three major ethnic groups, the Efik, the Ejagham and Bekwara.. Cross River State is one Nigeria's coastal State, 
located in the south-south region of the county, bordered by the Republic of Cameroon in the East and Nigeria state of Benue (North), Ebonyi and Abia (West) and Akwa Ibom (south-west ). It occupies a total land area of 10,156 square kilometers, lying between latitude $4^{0} 28^{0}$ and $6^{0} 55^{\circ}$ North of the equator and longitude $7^{0} 5^{0}$ and $9^{0} 28^{0}$ East of Greenwich meridian. It has an average annual temperature of $29^{\circ} \mathrm{c}$ and population of $2,888,966$ people (2006 NPC). Cross River State was created in May 27, 1967, named for Cross River (Oyono) which passes through the Sate located in the Niger Delta. Cross River State is divided into eighteen (18) local Government Area namely; Akpabuyo, Odukpani, Akamkpa, Biase, Ikom, Yarkuur, Obubra, Boki, Ogoja, Calabar-south, Etung, Bekwara, Bakassi, Calabar municipality. Obanliku, Obudu, Yala, Abi (Osang et al 2013).

\section{Data Source:}

The Data for Temperature $\left({ }^{0}, \mathrm{C}\right)$, Relative Humidity $(\%)$, wind speed $(\mathrm{m} / \mathrm{s})$, pressure (psi), Cloud Cover (oktas), Heat Radiation $\left(\mathrm{kw} / \mathrm{m}^{3}\right)$, wind Direction, $\mathrm{NO}_{2}(\mathrm{ppm}), \mathrm{NO}(\mathrm{ppm}), \mathrm{O}_{2}, \mathrm{SO}_{2}(\mathrm{ppm}), \mathrm{H}_{2} \mathrm{~S}(\mathrm{ppm}), \mathrm{CO}_{2}$, VOC(ppm), $\mathrm{NH}_{3}(\mathrm{ppm}), \mathrm{SPM}$ (ppm) and Noise dBA were Collected from Environmental Impact Assessment (EIA) Cross River State Ministry of Environment in conjunction with Niger Delta Development Commission On which Cover a period of two years (October 2010 to september 2012)

\section{Result}

Table 2: Air Quality Parameters in Calabar for Dry season (Oct.2010-March2011)

$$
\text { Result }
$$

\begin{tabular}{|c|c|c|c|c|c|c|c|c|c|c|c|c|}
\hline Month & $\begin{array}{l}\mathrm{NO}_{2} \\
\mathrm{ppm}\end{array}$ & $\begin{array}{l}\text { NO } \\
\text { ppm }\end{array}$ & $\mathrm{O}_{2}$ & $\begin{array}{l}\mathrm{SO}_{2} \\
\mathrm{ppm}\end{array}$ & $\begin{array}{l}\mathrm{H}_{2} \mathrm{~S} \\
\mathrm{ppm}\end{array}$ & $\mathrm{C} 0 \mathrm{ppm}$ & $\mathrm{CO}_{2}$ & V0C ppm & $\mathrm{NH}_{3} \mathrm{ppm}$ & $\mathrm{CH}_{4} \mathrm{ppm}$ & $\begin{array}{l}\text { SPM } \\
\mathrm{ppm}\end{array}$ & Noise dBA \\
\hline October & 0.0 & 0.0 & 19.9 & 0.9 & 0.1 & 0.0 & 0.0 & 0.0 & 0.0 & 0.0 & 0.99 & 54 \\
\hline November & 0.0 & 0.0 & 20 & 2.1 & 0.1 & 0.0 & 0.0 & 0.0 & 0.0 & 0.0 & 0.098 & 55.1 \\
\hline December & 0.0 & 0.0 & 19.98 & 0.99 & 0.1 & 0.0 & 0.0 & 0.0 & 0.0 & 0.0 & 0.099 & 51.9 \\
\hline January & 0.0 & 0.0 & 21.01 & 3.41 & 0.1 & 0.0 & 0.0 & 0.0 & 0.0 & 0.0 & 1.03 & 52 \\
\hline February & 0.0 & 0.0 & 20.09 & 1.87 & 0.1 & 0.0 & 0.0 & 0.0 & 0.0 & 0.0 & 1.11 & 54.1 \\
\hline March & 0.0 & 0.0 & 20 & 2.39 & 0.1 & 0.0 & 0.0 & 0.0 & 0.0 & 0.0 & 0.99 & 50.8 \\
\hline Mean & 0.0 & 0.0 & 20.16 & 1.94 & 0.1 & 0.0 & 0.0 & 0.0 & 0.0 & 0.0 & 0.098 & 52.98333333 \\
\hline Range & - & - & $\begin{array}{r}19.98- \\
21.0\end{array}$ & $\begin{array}{l}0.9- \\
3.41 \\
\end{array}$ & & & & & & & 1.1 & $50.8-55.1$ \\
\hline DPR & & & & & & $20 \mathrm{ppm}$ & & 0.16 & & & & \\
\hline Limits & & & & & & & & & & & & \\
\hline
\end{tabular}

Source: Fieldwork (2010-2011)

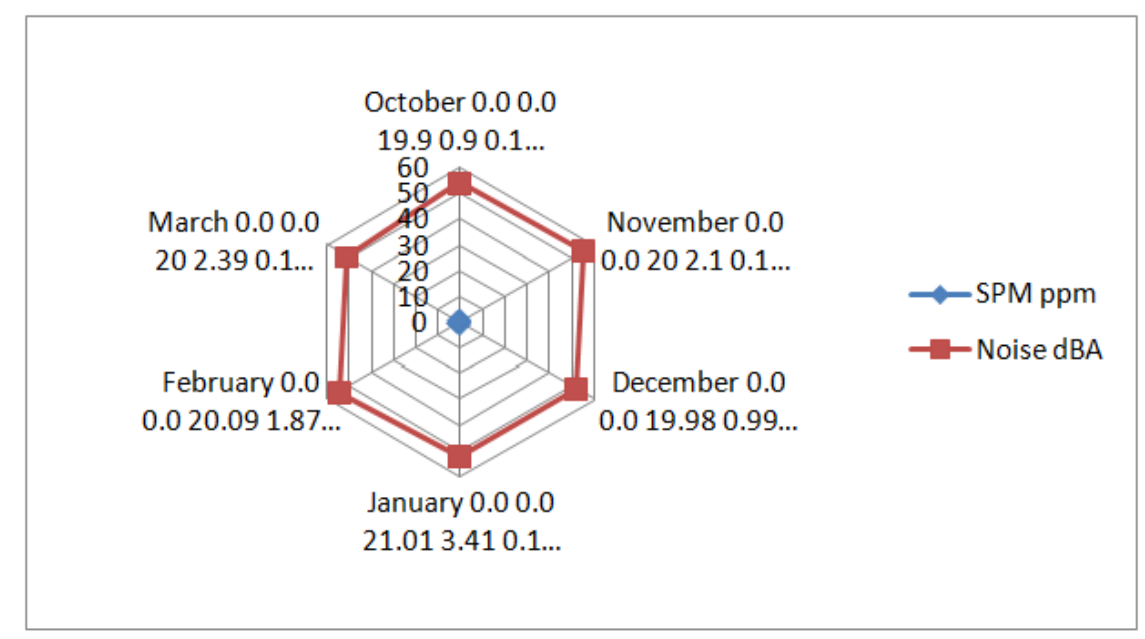

Fig 1: Random plot of SPM and noise for Calabar (Oct.2010-March2011) 


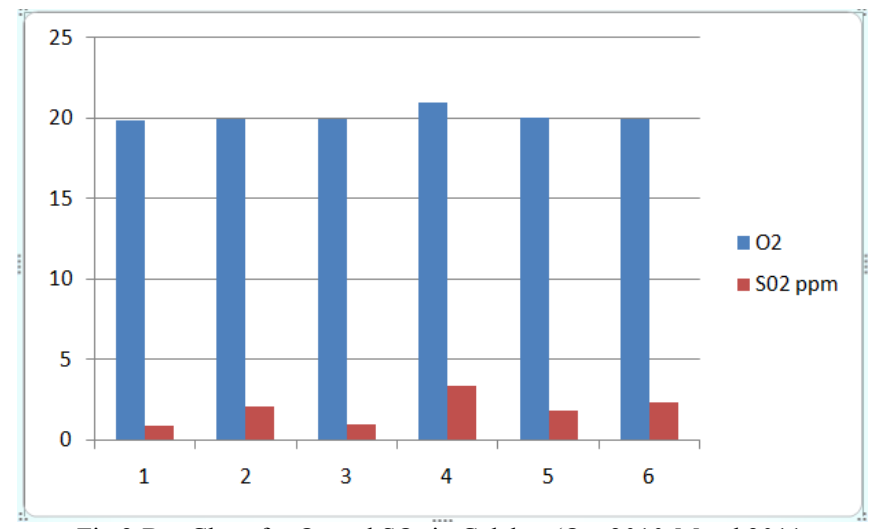

Fig 2:Bar Chart for $\mathrm{O}_{2}$ and $\mathrm{SO}_{2}$ in Calabar (Oct.2010-March2011

Table 3: Air Quality Parameters in Calabar for wet season (April 2011-Sept.2011)

\begin{tabular}{|c|c|c|c|c|c|c|c|c|c|c|c|c|}
\hline MONTH & $\begin{array}{l}\text { NO2 } \\
\text { ppm }\end{array}$ & $\begin{array}{l}\text { NO } \\
\text { ppm } \\
\end{array}$ & $\mathbf{O 2}$ & $\begin{array}{l}\text { S02 } \\
\text { ppm }\end{array}$ & $\begin{array}{l}\text { H2S } \\
\text { ppm }\end{array}$ & $\begin{array}{l}\mathrm{CO} \\
\text { ppm } \\
\end{array}$ & $\mathrm{CO2}$ & $\begin{array}{l}\mathrm{V0C} \\
\mathrm{ppm}\end{array}$ & $\begin{array}{l}\text { NH3 } \\
\text { ppm }\end{array}$ & $\begin{array}{l}\text { CH4 } \\
\text { ppm }\end{array}$ & $\begin{array}{l}\text { SPM } \\
\text { ppm }\end{array}$ & $\begin{array}{l}\text { Noise } \\
\text { dBA }\end{array}$ \\
\hline APRIL & $<0.1$ & $<0.1$ & 20.94 & $<0.1$ & 0.1 & $<0.1$ & $<0.1$ & 0.0 & 0.0 & $<0.1$ & 0.001 & 50.3 \\
\hline MAY & $<0.1$ & $<0.1$ & 20.93 & $<0.1$ & 0.1 & $<0.1$ & $<0.1$ & 0.0 & 0.0 & $<0.1$ & 0.002 & 48.9 \\
\hline JUNE & $<0.1$ & $<0.1$ & 20.91 & 3 & 0.1 & $<0.1$ & $<0.1$ & 0.0 & 0.0 & $<0.1$ & 0.002 & 50.6 \\
\hline JULY & $<0.1$ & $<0.1$ & 20.9 & 45 & 0.1 & $<0.1$ & $<0.1$ & 0.0 & 0.0 & $<0.1$ & 0.001 & 50.4 \\
\hline AUGUST & $<0.1$ & $<0.1$ & 21 & 3 & 0.1 & $<0.1$ & $<0.1$ & 0.0 & 0.0 & $<0.1$ & 0.001 & 49.3 \\
\hline SEPTEMBER & $<0.1$ & $<0.1$ & 20.92 & 2 & 0.1 & $<0.1$ & $<0.1$ & 0.0 & 0.0 & 680 & 0.001 & 50.5 \\
\hline MEAN & $<0.1$ & $<0.1$ & 20.93 & 13.25 & 0.1 & $<0.1$ & $<0.1$ & 0.0 & 0.0 & 113.3 & & 50.0 \\
\hline Range & - & - & $\begin{array}{r}20.90- \\
21.0 \\
\end{array}$ & $\begin{array}{l}0.1- \\
45 \\
\end{array}$ & & & & & & & & \\
\hline \multicolumn{13}{|l|}{ DPR } \\
\hline Limits & & & & & & $20 \mathrm{ppm}$ & & 0.16 & & & & \\
\hline
\end{tabular}

Source: Fieldwork (2011)

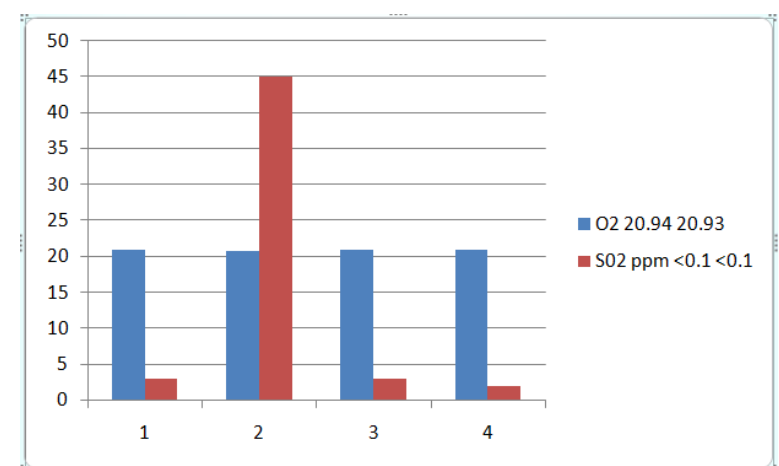

Fig 3: Bar chart for $\mathrm{O}_{2}$ and $\mathrm{SO}_{2}$ (April 2011-Sept.2011)

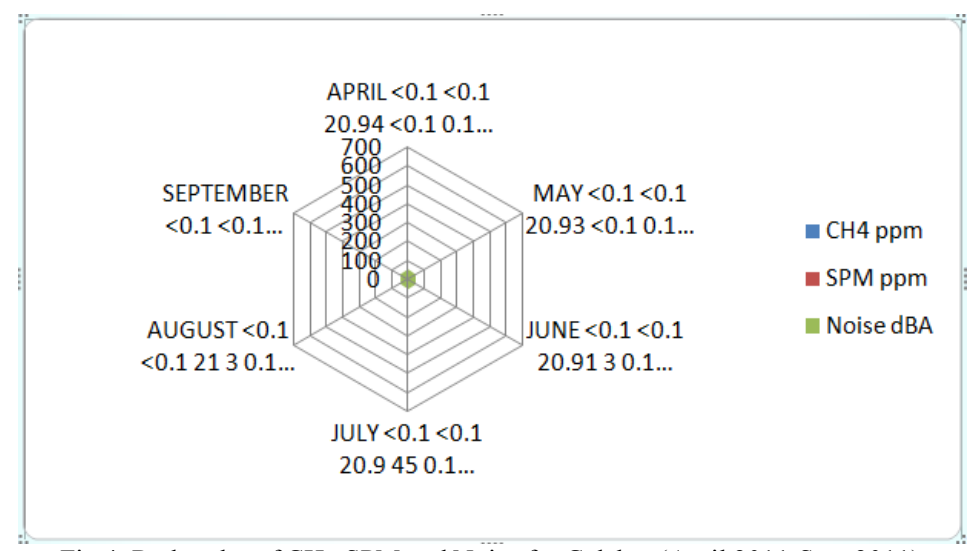

Fig 4: Radar plot of $\mathrm{CH}_{4}$, SPM and Noise for Calabar (April 2011-Sept.2011) 
Air Quality And Environmental Helath In Calabar, Cross River State, Nigeria.

Fig. 4: Air Quality Parameters in Calabar for Dry season (Oct.2011-March2012)

\begin{tabular}{|c|c|c|c|c|c|c|c|c|c|c|c|c|}
\hline Month & $\begin{array}{l}\text { No2 } \\
\text { ppm }\end{array}$ & $\begin{array}{l}\text { NO } \\
\text { ppm }\end{array}$ & $\mathbf{O 2}$ & $\begin{array}{l}\text { S02 } \\
\text { ppm }\end{array}$ & $\begin{array}{l}\text { H2S } \\
\text { ppm }\end{array}$ & $\begin{array}{l}\text { C0 } \\
\text { ppm }\end{array}$ & $\mathrm{CO2}$ & $\begin{array}{l}\text { V0C } \\
\text { ppm }\end{array}$ & $\begin{array}{l}\text { NH3 } \\
\text { ppm }\end{array}$ & $\begin{array}{l}\text { CH4 } \\
\text { ppm }\end{array}$ & SPM ppm & Noise dBA \\
\hline October & 0.0 & 0.0 & 19.95 & 0.9 & 0.1 & 0.0 & 0.0 & 0.0 & 0.0 & 0.0 & 0.99 & 55.2 \\
\hline November & 0.0 & 0.0 & 20 & 3.45 & 0.1 & 0.0 & 0.0 & 0.0 & 0.0 & 0.0 & 0.099 & 55.1 \\
\hline December & 0.0 & 0.0 & 19.98 & 0.99 & 0.1 & 0.0 & 0.0 & 0.0 & 0.0 & 0.0 & 0.119 & 51.9 \\
\hline January & 0.0 & 0.0 & 21.06 & 3.41 & 0.1 & 0.0 & 0.0 & 0.0 & 0.0 & 0.0 & 1.03 & 52 \\
\hline February & 0.0 & 0.0 & 20.09 & 1.87 & 0.1 & 0.0 & 0.0 & 0.0 & 0.0 & 0.0 & 1.16 & 50.8 \\
\hline Mean & 0.0 & 0.0 & 20.44667 & 2.124 & 0.1 & 0.0 & 0.0 & 0.0 & 0.0 & 0.0 & 0.76466667 & 52.63333333 \\
\hline Range & - & - & $\begin{array}{r}19.95- \\
21.6 \\
\end{array}$ & $\begin{array}{l}0.9- \\
3.45\end{array}$ & & & & & & & 0.99 .1 .19 & $50.8-55.2$ \\
\hline DPR & & & & & & $20 \mathrm{ppm}$ & & 0.16 & & & & \\
\hline Limits & & & & & & & & & & & & \\
\hline
\end{tabular}

Source: Fieldwork (2011-2012)

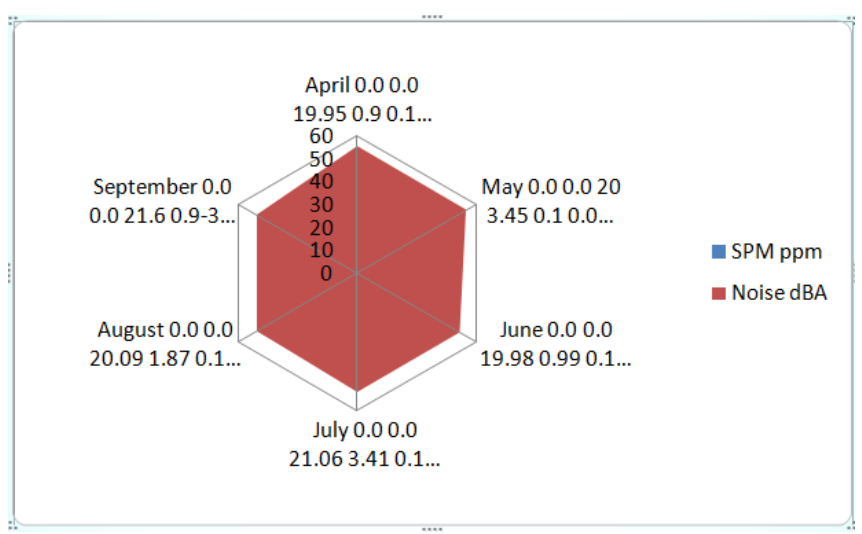

Fig 5: Radar plot of $\mathrm{CH}_{4}$, SPM and Noise for Calabar (April 2011-Sept.2012)

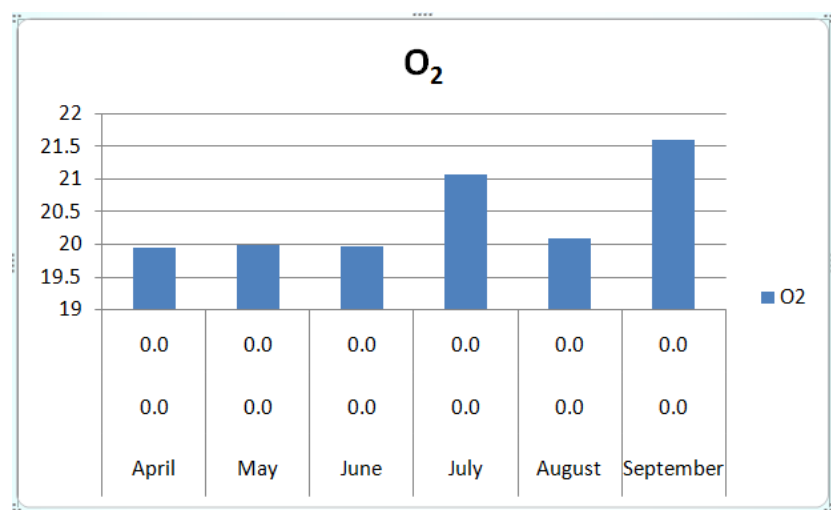

Fig 6: Bar chart for $\mathrm{O}_{2}$ in Calabar (Oct.2011-March2012)

Table 5. : Air Quality Parameters in Calabar for wet season (April 2012-Sept.2012)

\begin{tabular}{|c|c|c|c|c|c|c|c|c|c|c|c|c|}
\hline MONTH & $\begin{array}{l}\text { No2 } \\
\text { ppm }\end{array}$ & $\begin{array}{l}\text { NO } \\
\text { ppm }\end{array}$ & $\mathbf{O 2}$ & $\begin{array}{l}\text { S02 } \\
\text { ppm }\end{array}$ & $\begin{array}{l}\text { H2S } \\
\text { ppm }\end{array}$ & $\begin{array}{l}\text { C0 } \\
\text { ppm }\end{array}$ & $\mathrm{CO2}$ & $\begin{array}{l}\text { V0C } \\
\text { ppm }\end{array}$ & $\begin{array}{l}\text { NH3 } \\
\text { ppm }\end{array}$ & $\begin{array}{l}\text { CH4 } \\
\text { ppm }\end{array}$ & $\begin{array}{l}\text { SPM } \\
\text { ppm }\end{array}$ & Noise dBA \\
\hline APRIL & $<0.1$ & $<0.1$ & 20.92 & $<0.1$ & 0.1 & $<0.1$ & $<0.1$ & 0.0 & 0.0 & $<0.1$ & 0.001 & 49 \\
\hline MAY & $<0.1$ & $<0.1$ & 21.4 & $<0.1$ & 0.1 & $<0.1$ & $<0.1$ & 0.0 & 0.0 & $<0.1$ & 0.002 & 48.9 \\
\hline JUNE & $<0.1$ & $<0.1$ & 20.91 & 3 & 0.1 & $<0.1$ & $<0.1$ & 0.0 & 0.0 & $<0.1$ & 0.002 & 50.6 \\
\hline JULY & $<0.1$ & $<0.1$ & 20.9 & 40 & 0.1 & $<0.1$ & $<0.1$ & 0.0 & 0.0 & $<0.1$ & 0.001 & 50.9 \\
\hline AUGUST & $<0.1$ & $<0.1$ & 21.5 & 2 & 0.1 & $<0.1$ & $<0.1$ & 0.0 & 0.0 & $<0.1$ & 0.001 & 49.3 \\
\hline SEPTEMBER & $<0.1$ & $<0.1$ & 20.92 & 2 & 0.1 & $<0.1$ & $<0.1$ & 0.0 & 0.0 & 650 & 0.001 & 49.6 \\
\hline MEAN & $<0.1$ & $<0.1$ & 21.09167 & 11.75 & 0.1 & $<0.1$ & $<0.1$ & 0.0 & 0.0 & 108 & & 49.71666667 \\
\hline Range & - & - & $\begin{array}{r}20.90- \\
21.5\end{array}$ & $\begin{array}{l}0.1- \\
40\end{array}$ & & & & & & & & $49.0-50.9$ \\
\hline \multicolumn{13}{|l|}{ DPR } \\
\hline Limits & & & & & & $20 \mathrm{ppm}$ & & 0.16 & & & & \\
\hline
\end{tabular}


Source: Fieldwork (2011)

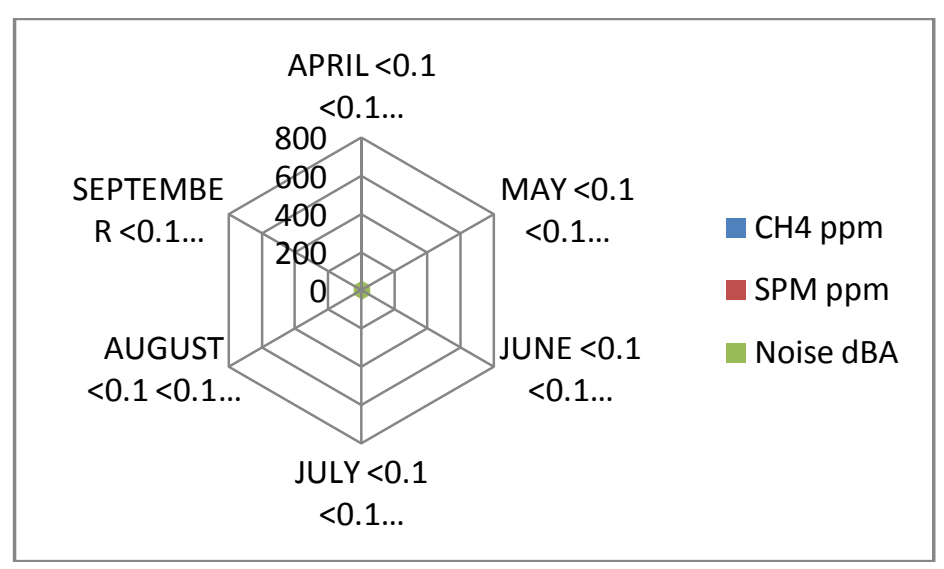

Fig 7: Radar plot of $\mathrm{CH}_{4}$, SPM and Noise for Calabar (April 2012-Sept.2012)

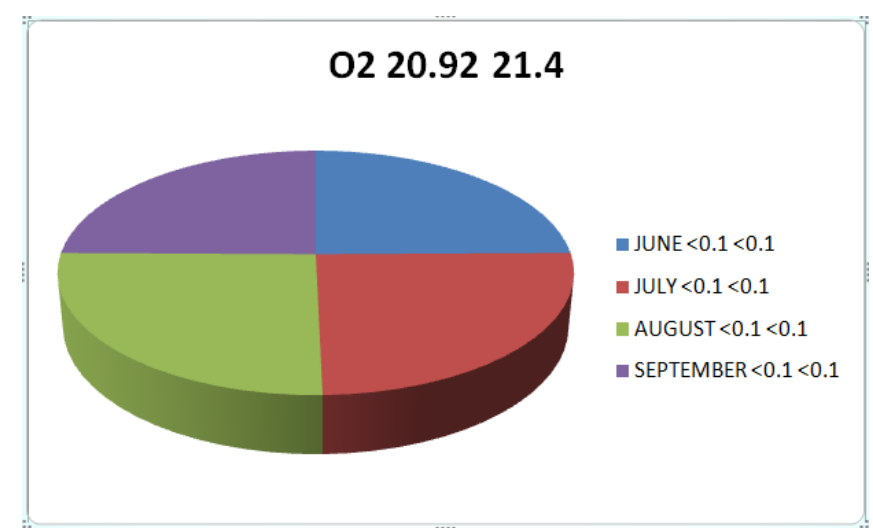

Fig 8: Pie chart for $\mathrm{O}_{2}$ Air Quality Results (April 2012-Sept.2012)

\begin{tabular}{|c|c|c|c|c|c|c|c|c|}
\hline Month & Season & Temperature & $\begin{array}{l}\text { Relative } \\
\text { Humidity (\%) } \\
\end{array}$ & $\begin{array}{l}\text { Wind vel. } \\
(\mathrm{m} / \mathrm{s})\end{array}$ & $\begin{array}{l}\text { Pressure } \\
\text { Psi } \\
\end{array}$ & $\begin{array}{l}\text { Cloud cover } \\
\text { (oktas) }\end{array}$ & $\begin{array}{l}\text { Heat } \\
\text { Radiation } \\
(\mathrm{kw} / \mathrm{m} 3) \\
\end{array}$ & $\begin{array}{l}\text { Wind } \\
\text { Direction }\end{array}$ \\
\hline October & Dry & 32.8 & 31 & 1.11 & 1011 & 4 & 2.23 & SE \\
\hline November & Dry & 33 & 29.2 & 1.1 & 1090 & 4.1 & 2.04 & SE \\
\hline December & Dry & 33 & 29.2 & 1 & 1001 & 4.1 & 2.9 & SE \\
\hline January & Dry & 33 & 29.7 & 1 & 1010 & 4 & 2.44 & SE \\
\hline February & Dry & 33 & 29 & 1.4 & 1009 & 4 & 2.3 & SE \\
\hline March & Dry & 33 & 29.1 & 1.1 & 1001 & 4.2 & 2.81 & \\
\hline Range & & 32.833 .0 & $29-31$ & $1-1.4$ & 1001 & 44.2 & $2.3-2.45$ & \\
\hline Mean & & 23.96 & 29.53333333 & 1.118333333 & $\begin{array}{l}1011 \\
1020.33\end{array}$ & 4.06 & 2.453333333 & \\
\hline
\end{tabular}

Source: Fieldwork (2010- 2011) 


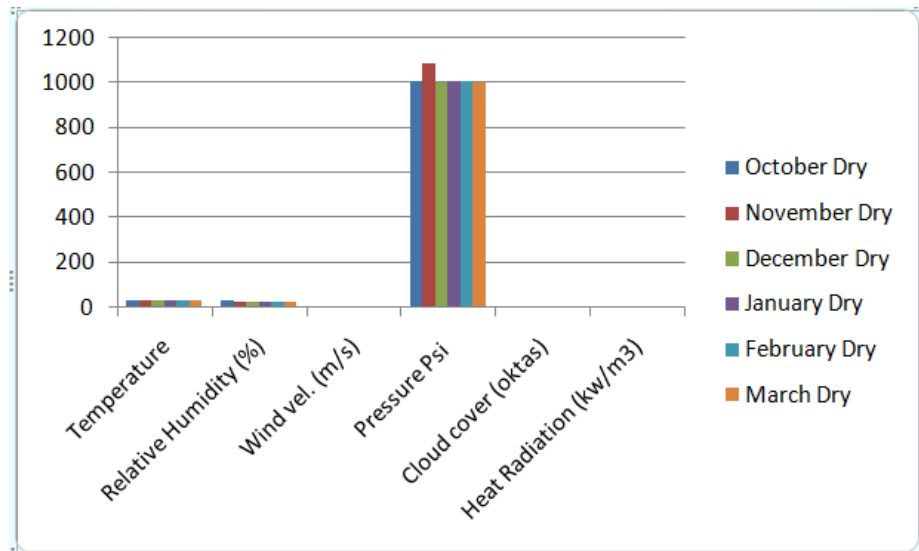

Fig 9: Bar chart for Climate Data for dry season in Calabar (2010-2011)

Table 7: Climatic data for wet season in Calabar (April 2011-Sept.2011)

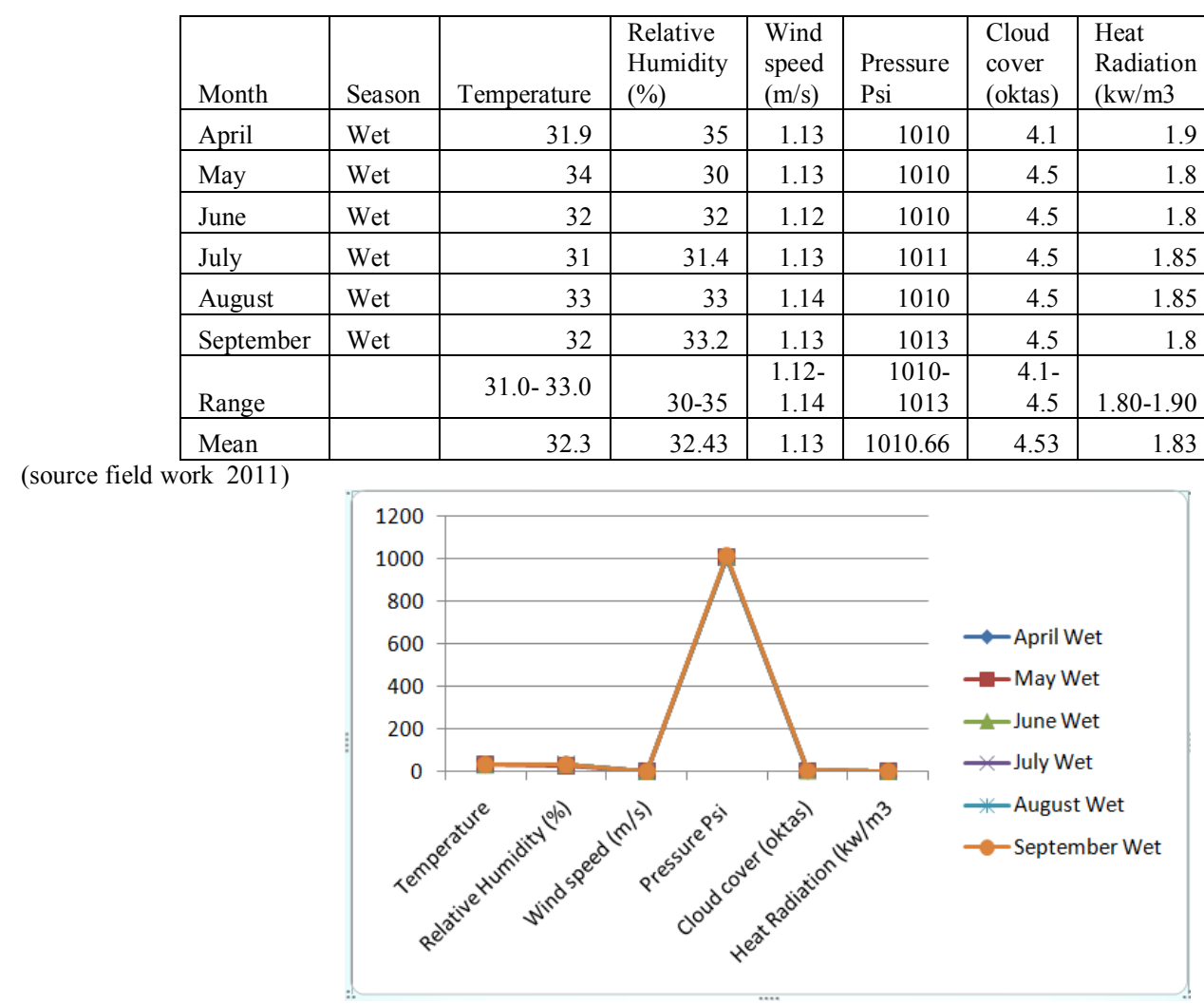

Fig 10: Bar chart for Climate Data (April 2011-Sept.2011)

Table 8: Climatic data for dry season in Calabar (Oct. 2011-.2012)

\begin{tabular}{|l|l|r|r|r|r|r|r|l|}
\hline & & & $\begin{array}{l}\text { Relative } \\
\text { Mumidity } \\
\text { Month }\end{array}$ & Season & $\begin{array}{l}\text { Wind vel } \\
(\mathbf{m} / \mathbf{s})\end{array}$ & $\begin{array}{l}\text { Cloud } \\
\text { Pover } \\
\text { Pressure Psi }\end{array}$ & $\begin{array}{l}\text { Heat } \\
\text { Radiation } \\
\text { (kw/m3) }\end{array}$ & $\begin{array}{l}\text { Wind } \\
\text { Direction }\end{array}$ \\
\hline October & Dry & 32.3 & 34.0 & 1.14 & 1011 & 4.0 & 2.91 & SE \\
\hline November & Dry & 33.1 & 29.2 & 1.1 & 1090 & 4.2 & 2.22 & SE \\
\hline December & Dry & 33 & 29.2 & 1 & 1001 & 4.1 & 2.93 & SE \\
\hline January & Dry & 33 & 29.4 & 1 & 1010 & 4.3 & 2.44 & SE \\
\hline February & Dry & 33 & 29 & 1.4 & 1009 & 4 & 2.3 & SE \\
\hline March & Dry & 33 & 29.1 & 1.1 & 1001 & 4.2 & 2.5 & \\
\hline Range & & $32.3-33.1$ & $29-34$ & $1-1.14$ & 1001 & $4-4.3$ & $2.22-2.5$ & \\
\hline Mean & & 32.9 & 29.98333333 & 1.123333333 & 1020.333333 & 4.16 & 2.55 & \\
\hline
\end{tabular}

Source: Fieldwork, 2011-2012 


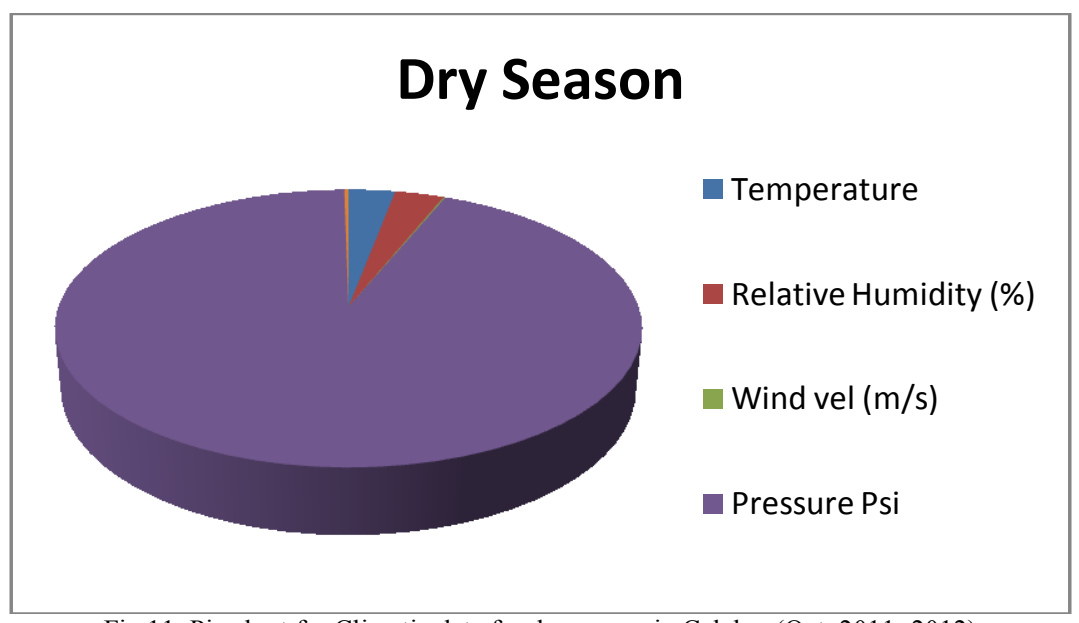

Fig 11: Pie chart for Climatic data for dry season in Calabar (Oct. 2011-.2012)

Table 9: : Climatic data for wet season in Calabar (April 2012-Sept.2012)

\begin{tabular}{|c|c|c|c|c|c|c|c|c|}
\hline Month & Season & Temperature & $\begin{array}{l}\text { Relative } \\
\text { Humidity } \\
(\%)\end{array}$ & $\begin{array}{l}\text { Wind speed } \\
(\mathrm{m} / \mathrm{s})\end{array}$ & Pressure Psi & $\begin{array}{l}\text { Cloud } \\
\text { cover } \\
\text { (oktas) }\end{array}$ & $\begin{array}{l}\text { Heat } \\
\text { Radiation } \\
(\mathrm{kw} / \mathrm{m} 3\end{array}$ & $\begin{array}{l}\text { Wind } \\
\text { Direction }\end{array}$ \\
\hline April & Wet & 32 & 33 & 1.15 & 1011 & 4.6 & 1.82 & SE \\
\hline May & Wet & 34 & 30 & 1.1 & 1010 & 4.5 & 1.95 & SE \\
\hline June & Wet & 32 & 32 & 1.12 & 1010 & 4.5 & 1.8 & SE \\
\hline July & Wet & 31 & 31.4 & 1.13 & 1012 & 4.1 & 1.85 & $\mathrm{SE}$ \\
\hline August & Wet & 31 & 31 & 1.14 & 1010 & 4.5 & 1.85 & $\mathrm{SE}$ \\
\hline September & Wet & 34 & 31.2 & 1.13 & 1012 & 4.5 & 1.81 & \\
\hline Range & & $31.0-34.0$ & $30-33$ & $1.10-1.15$ & 1010-1012 & $\begin{array}{r}4.1- \\
4.6 \\
\end{array}$ & $1.82-1.95$ & \\
\hline Mean & & 32.33333333 & 31.43333333 & 1.128333333 & 1010.833333 & 4.45 & 1.846666667 & \\
\hline
\end{tabular}

Source: Fieldwork, 2012

\section{Discussion of Results \\ Air Quality Parameters}

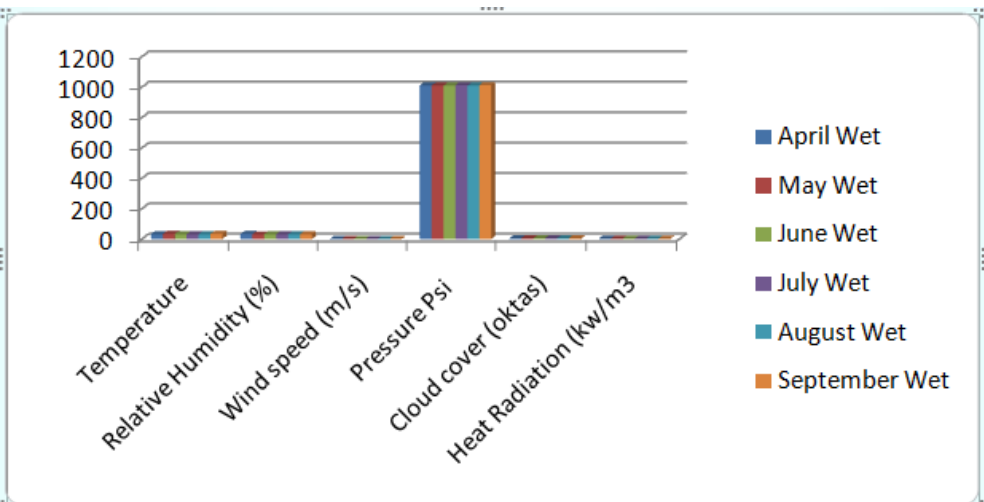

Fig 12: Bar chart for Climate in Calabar (April 2012-Sept.2012)

Based on the results of air quality parameters monitored during the sampling period which are shown in Table 2,3,4, 5 and fig. 1,2,3,4,5,6,7,8 above. The values obtained from the sampling locations indicated the following observations.

- $\mathrm{Co}, \mathrm{Co}_{2}, \mathrm{No}_{2}, \mathrm{Ho}_{2} \mathrm{H}_{3}$ were below detection levels and therefore absent indicating the absence of appreciable quatity of these pollutant indicators in the ambient air;

* VOCs were not detected and therefore recorded 0.0

- $\mathrm{O}_{2}$ ranged from $19.95-21.0,19.95-21.6 \%$ and 20.90-210, 20.90- $21.5 \%$ for the dry and wet seasons respectively; which is in line with the standard of Air Quality index (AQI) Values.

- $\mathrm{CH}_{4}$ values were below detection except in one station where a value of 680 and 650ppm were recorded during wet season sampling period. which is not in line with the standard of Air Quality index (AQI) Values. 
* $\mathrm{SO}_{2}$ ranged from 0.9-3.41, 0.9-3.45 and 0.1-45, 0.1-40 for the dry and wet seasons respectively; which is writhin acceptable limits of the standard of Air Quality index (AQI) Values.

The results for climatic data monitored in the Calabar Area during the study period are presented in table $6,7,8,9$ and fig 9,10,11,12. They shows the following:

Rainfall: The study areas are characterized by two dominant seasons, the dry and wet. The dry season begins in October and ends in March and is defined by the North-East Trade Winds, which brings harmattan, which is very cold. The wet season starts from April and ends in October and characterized by South-West winds, which are moisture laden from the Atlantic Ocean.

The study area experiences rainfall, with annual total in excess of $2,294 \mathrm{~mm}$. the lowest rainfall reported occurs during the dry season in the months of December/January/February while the highest rainfall occurs in the months of July/August/September. Sampling was done during dry sunny days in both seasons and so daily rainfall data were not taken during the study.

\section{Temperature/Heat radiation/ Cloud Cover}

Table $6,7,8,9$ indicate temperatures ranges of 31.0 to $34.0^{\circ} \mathrm{c}$ for this wet season and $32.833 .0^{\circ} \mathrm{c}$ for the dry season for the sampling period. The mean values were $32.3^{\circ} \mathrm{c}$ for the wet season and $23.96^{0} \mathrm{c}$ for dry season.

The values for radiation were generally low indicating raining values range form $1.801 .90\left(\mathrm{kw} / \mathrm{m}^{3}\right)$ and $2.042 .90\left(\mathrm{kw} / \mathrm{m}^{3}\right)$ with a mean value of $1.83\left(\mathrm{kw} / \mathrm{m}^{3}\right)$ and $2.45\left(\mathrm{kw} / \mathrm{m}^{3}\right)$ for the wet and dry seasons respectively(table ).

\section{Relative Humidity}

The mean daily RH recorded during the study period ranged from $30 \%-35 \%$ for the wet season and $29.031 . \%$ for the dry season. The mean values were $32.43 \%$ and $29.53 \%$ for the wet and dry seasons respectively.

\section{Wind Direction/Wind Velocity}

The dominant wind direction was the south-easterly wind of the study area for this wet season period. The surface wind velocity monitored above the ground level during the sampling periods were generally low with a range of 1.12 to $1.14 \mathrm{~m} / \mathrm{s}$ and $1.001 .40 \mathrm{~m} / \mathrm{s}$ with mean values of $1.13 \mathrm{~m} / \mathrm{s}$ and $1.11 \mathrm{~m} / \mathrm{s}$ for the wet and dry seasons respectively (table 6,7,8,9 and fig 9,10,11,12).

* The suspended particulate matter (SPM) ranged from $0.001 \quad 0.002 \mathrm{pg} / \mathrm{m}^{3}$ for the wet season period; values being lower than the speculated limits $\left(150230 \mathrm{Ug} / \mathrm{m}^{3}\right.$ ) of the DPR (table 6,7,8,9 and fig 9,10,11,12).

\section{Summary/ Conclusion}

Air pollution has important and diverse health effects on everybody on earth. There is a compelling need to move forward on efforts to ensure clean air for all.

Finding solutions to these and other air pollution problems isn't always easy, and requires agencies, environmental organizations, industry, Governments and the public to work together to ensure clean air. The department of Health should work closely together with Government agencies, the public and others who are concerned about air quality to;

- Provide consultation, trainings, and presentations to schools, local health agencies, regulated parties, and others regarding a variety of air quality issues.

- Enforce the clean indoor Air Act, which regulates smoking in indoor and public places.

- Encourage testing and reduction of radon in homes, through educational efforts.

- Conduct site-specific assessments of health risks from air pollutants emitted by industries, hazardous waste sites, feedlots, and other pollution sources.

- Evaluate the effects of air pollution on vulnerable populations, such as children and people with respiratory diseases so that risk assessment methods are adequately protective of human health.

- Develop Health-Based Rules and Guidance for Air used for site- specific assessments and air permit reviews.

- Track research about the health effects of air pollutants on an ongoing basis, and incorporate new methods and data into health risk assessments and best practices guidelines.

- $\quad$ Reduce mercury air emissions

\section{Reference}


[1]. Agency for toxic substance and Disease registry http//ww.atsdr. cdc. gov/general/theair.html Accessed on $5^{\text {th }}$ February, 2013 by 5:30pm.

[2]. Air Pollution and respiration Health http.//www. cdc. gov/nceh/airpollution accessed on the $5^{\text {th }}$ February, 2013 5:59pm.

[3]. Air Pollution and respiratory health; centre for disease control and prevention http://www.cdc.gov. retrieved 21/07/2013; 4:17pm.

[4]. Air pollution: http://www.niehs.nih.gov/health. retrieved 21/07/2013;05:15pm.

[5]. Air quality (out door) http:// haldon. ca/cms/one aspx? Portalld= 8310 \& page $1 \mathrm{~d}=1247$ retrieved $2 / 5 / 2013 \mathrm{at} 6.01 \mathrm{pm}$

[6]. Air Quality and Atmospheric and health. http://www.springer.com. Retrieved 21/07/2013; 4:015pm.

[7]. Air quality and health http://www.who. int/mediacentre/factsheets/fs $313 / \mathrm{en} /$ index.html Accessed on the $5^{\text {th }}$ February, 2013.

[8]. Air Quality and health http://www.who.int/media. retrieved 21/07/2013; 05:10pm.

[9]. Air Quality: ministry of health; http://www.health.gov.bc. Retrieved 21/07/2013.04:50pm.

[10]. Air Quality: Minnesota department of health. http://www.health.state. Retrieved 21/07/2013 4:08 pm

[11]. Air Quality-pm2.5 information http://www.co.missoula. Retrieved 21/07/2013;04:55pm.

[12]. Ambiant Air Pollution: Health Hazards to children http: pediatrics. aappublications. org/content 114/6/1699. full retrieved 2/5/2013: $4: 34 \mathrm{pm}$.

[13]. B.C. 's Air Quality Readings http.//www. bcairequality. ca/readings/index.html retrieved 2/5/2013, 5:26pm.

[14]. Bonfires, pollution control Air, clean Air Act. http://www.iwight.com. Retrieved 21/07/2013. 4:39pm.

[15]. CO2 transmitters http.//www. rotronic com/humidity - Measurement - feuchtemessing. retrieved 2/5/2013 at 5:49pm.

[16]. Current Air Quality in missoula http://www.missola. Retrieved 21/07/2013, 4:12pm.

[17]. Environmental Air Pollution Control system and precious metal Catalysts http://www. eas-inc.com accessed on the $5^{\text {th }}$ February, 2013 at 5:48pm.

[18]. Environmental and Environmental studies: Air Quality National Academic of science: http://www.nap.edu. Retrieved 21/07/2013. 04:59pm.

[19]. Environmental Hazard and Health effects http://www. cda. gov/nceh/ehhel Accessed on $5^{\text {th }}$ February, 2013 by 5:44pm.

[20]. Environmental Health http://ha waii.gov/health environment Accessed on the $5^{\text {th }}$ February, 2013 at 4:30pm.

[21]. Environmental Health, Air Quality. http://www.health.gov.st. Retrieved 21/07/2013. 4:35pm.

[22]. Environment impact assessment (EIA) Niger Delta Development Commission Ministry of Environment Cross River State, Calabar (2010-2012) October Report 2012.

[23]. Environmental services protecting and restoring what matter most. http://www.battelle.org. retrieved 21/07/2013; 05:03pm.

[24]. Igwe O. Ewona and Sunday O. Udo characteristic pattern of rainfall in Calabar Nigeria - A tropical coastal location (2008) Nigeria Journal of Physics 20(1) 2008.

[25]. Igwe O. Ewona, Emmanuel O. Obi and Ferdinand A. Kangba.Prospect of Biomass Energy in Niger Delta Region of Nigeria. 2011.

[26]. Indoor Air pollution: http://www.cieh.org. retrieved 21/07/2013, 04:45pm.

[27]. Indoor Air Quality $\{\mathrm{IAQ}\}$ in schools. http://www.health.state. Retrieved 21/07/2013. 04:53pm.

[28]. Indoor air quality http//en.wikipedia. org./wiki/indoor-air-quality Accessed on the $5^{\text {th }}$ February, 2013 at 5:26pm.

[29]. Indoor Air quality http://www. google. com. ng/search? $\mathrm{hl}=\mathrm{en} \times \mathrm{x}$ tbo $=1366 \mathrm{xbih}=5$ accessed on the $5^{\text {th }} \mathrm{February}, 2013$.

[30]. Minnesota Department of Health http/www health. state Mn. us/divs/eh/air/index. htm accessed on $5^{\text {th }}$ February 2013 by $5: 59 \mathrm{pm}$.

[31]. Osang, J.E, Obi E.O, Ewona, I.O Udoimuk A.B, Nnwankukwu. (2013) Review of Gas flaring Activities in Nigeria Delta Area of Nigeria. International Journal of Scientific and Engineering Research $h \mathrm{htp}$ ://www.ijsetr.org. Volume 4, Issue 9, September 2013 Edition

[32]. OSANG, Jonathan. Eyire., OBI, E. O., Ewona, I. O., IOSR Journal of Electronics and communication Engineering (IOSR-JECE) eISSN:2278-2834, P-ISSN:2278-8735. Volume 6 issue 3 (May=June 2013) pp 16-22. www.iosrjournals.org/iosr-jese/pages

[33]. Osang. J. E, Ewona I.O, Obi, E. O., Udoimuk A.,B., Kamgba, F.A. (2013) analyses of Radiation and Rainfall pattern in Kano State Northern Nigeria (1978-2007). International Journal of Scientific and Engineering Research http://www.ijser.org. Volume 4, Issue 9, September 2013 Edition

[34]. Ozone and Air Quality. http://www.health.state. Retrieved 21/07/2013.

[35]. S.O.Udo, I.O. Ewona and L.E. Akpabio Global Solar Radiation Distribution and Utilization season at Ilorin, Nigeria (2008) Nigeria Journal of Physics 20(1) 2008

[36]. SMD Not Air Pencil ZT-2 http/www.teph.com/pencil.html Accessed on the $5^{\text {th }}$ February, 2013

[37]. Sources of air pollutants http//www.google.com.ng/imgress? q=poor tairt quality and hl=en \& sa= Accessed on $5^{\text {th }}$ February, 2013. $5: 30 \mathrm{pm}$.

[38]. Obi E.O., Cherednichenko V.G.(2009)modeling of the Dynamics of oil spillage in a coastal Area. Ecology and industry of Russia: ISSN1816-0395 PP.34-35.

[39]. Obi, Emmanuel Odu (2008), Ecological impact of oil spillage on the environment Journal of food technology: ISSN0579-3009 PP.102-104.

[40]. Obi, Emmanuel Odu Shapasnikova T.L.(2008) mathematical modeling of oil spillage at the coastal water of Nigeria; 2008, ISSN: 1991-3087; Scientific Journal for P.H.D and Doctor of science research.

[41]. E. O. Obi, I. O. Ewona and D. A. Obi, 2008.Forest casting of Oil spillage at the coastal waters of the republic of Nigeria.International Journal of Natural and Applied Sciences (IJNAS) vol. 3, No 2 (2008). 